\title{
Japanese Primary Prevention of Atherosclerosis with Aspirin for Diabetes (JPAD) Trial
}

\section{小川 久雄}

〔日内会誌 $100 ： 218 ２ 23 ， 2011 〕$

Key words 糖尿病, アスピリン, 一次予防

\section{1.はじめに}

循環器領域では, 1980 年代から欧米において 臨床研究が盛んに行われ, 心筋梗塞の二次予防 としてのアスピリンの有効性は, The Second International Study of Infarct Survival (ISIS-2) triall $^{1)}$ において確立し, $\beta$ 遮断薬も心筋梗塞の死亡 を減少させるという結果 ${ }^{2}$ より心筋梗塞二次予防 における重要性が認められる事となった。ささら に, 急性心筋梗塞後の心不全ならびに左心機能 低下例を対象としたSAVE試験 ${ }^{3)} に て A C E$ 阻害薬 の有用性が示された。 また, 冠動脈疾患を有す る患者の二次予防としてのスタチンによる心血 管イベントの減少に関しては多くのエビデンス が得られた ${ }^{4,5}$.

我々は 1994 年から心筋梗塞二次予防のエビデ ンスの創出を目指して臨床研究に取り組んでき た。この頃は臨床研究の評価が低く全く評価さ れなかった。しかし，近年その機運が急速に盛
り上がりつつある. まず行ったのがアスピリン の再梗塞予防に関するエビデンスであるJapanese Antiplatelets Myocardial Infarction Study $(\mathrm{JAMIS})^{6)}$, 次に欧米の心筋梗塞の二次予防ガイ ドラインにおいて $\beta$ 遮断薬の使用が記載されてい るにも関わらず日本ではJAMISにおいて $\beta$ 遮断薬 の使用頻度は少なくCa拮抗薬が多い点を批判さ れたため, 1998 年から行ったのがCa拮抗薬と $\beta$ 遮断薬の比較試験Japanese $\beta$-blockers and Calcium antagonists Myocardial Infarction (JBCMI)Study ${ }^{7}$ である. 前述のように, この頃 欧米においては冠動脈疾患二次予防におけるス タチン療法の効果は確立していたが日本では未 だ十分なエビデンスが揃っているとは言い難く, JBCMI Studyでもスタチンの使用は $25 \%$ であっ た. そのため 2002 年から行ったのがスタチン療 法の効果をみたMulticenter Study for Aggressive Lipid-lowering Strategy by HMG-CoA Reductase Inhibitors in Patients with Acute Myocardial Infarction(MUSASHI-AMI) ${ }^{8)}$ であった.

熊本大学大学院生命科学研究部循環器病態学

Series, Clinical Study from Japan and its Reflections ; Japanese Primary Prevention of Atherosclerosis with Aspirin for Diabetes (JPAD) Trial.

Hisao Ogawa : Department of Cardiovascular Medicine, Graduate School of Medical Sciences Kumamoto University, Japan. 


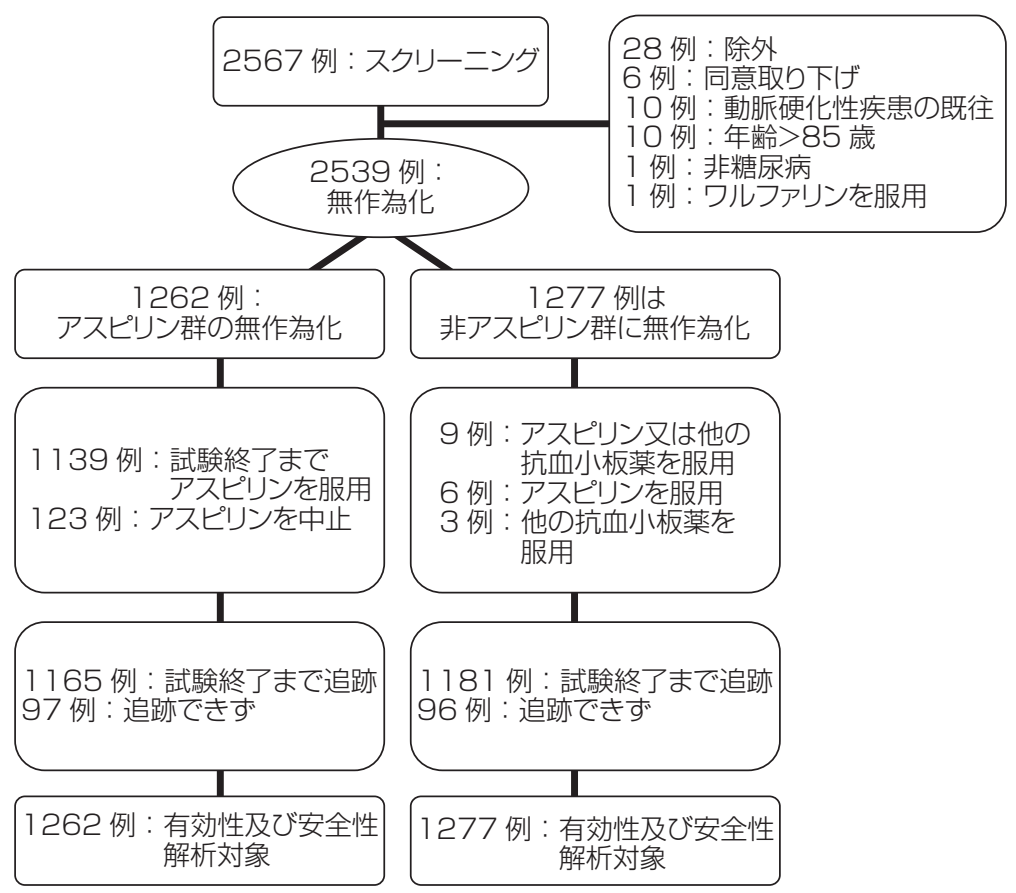

図 1. JPAD Trial 対象患者のフローチャート（文献 9 より引用）

そして糖尿病の心筋梗塞や脳梗塞における重要 性を認識し一次が重要であると考え, 2002 年 12 月から一次予防試験であるJapanese Primary Prevention of Atherosclerosis with Aspirin for Diabetes (JPAD) Trial ${ }^{9}$ に取り組んだ。本稿で はJPAD Trialについて解説し, その意義や問題 点について述べる.

\section{Japanese Primary Prevention of Athe- rosclerosis with Aspirin for Diabetes (JPAD) Trial}

本研究は, 日本人の糖尿病患者にアスピリン の一次予防効果はあるかという事を検証する目 的で行われた一次予防の成績である. 2 型糖尿病 で, 年齢は 30〜85 歳, 虚血性心疾患や脳卒中な ど動脈硬化性疾患の既往のない男女 2,539 人を対 象とした。低用量アスピリン $(81 \mathrm{mg} /$ 日または $100 \mathrm{mg} /$ 日) 投与群と非アスピリン投与群に無作
為に割りつけて検討した。追跡期間中に起こっ た動脈硬化性複合イベント(突然死, 冠動脈/脳 血管/大動脈が原因の死亡, 非致死性急性心筋梗 塞, 不安定狭心症, 新たに起こった労作性狭心 症, 非致死性脳卒中, 一過性脳虚血発作, 非致 死性大動脈/末梢血管疾患)の発生を一次エンド ポイントとした. 日本国内の 163 施設が参加し た，多施設共同ランダム化比較試験 $(\mathrm{RCT})$ で, PROBE (prospective, randomized, open-label, controlled trial with blinded end-point assessment)法で行った. 2,539 人が, 低用量アスピリ ン群 1,262 人とコントロール群 1,277 人にランダ ムに割り付けられた．追跡期間の中央值は 4.37 年であった（図 1).

追跡期間中に, アスピリン群で 68 人 $(68 / 1,262=$ $5.4 \%)$, コントロール群で 86 人 $(86 / 1,277=6.7 \%)$ にイベントが発生した。 アスピリン群で少ない 傾向にあったが，ハザード比は 0.80 (95\% 信頼 区間 0.58〜 1.10, $\mathrm{p}=0.16)$ で，両群間に有意差は 


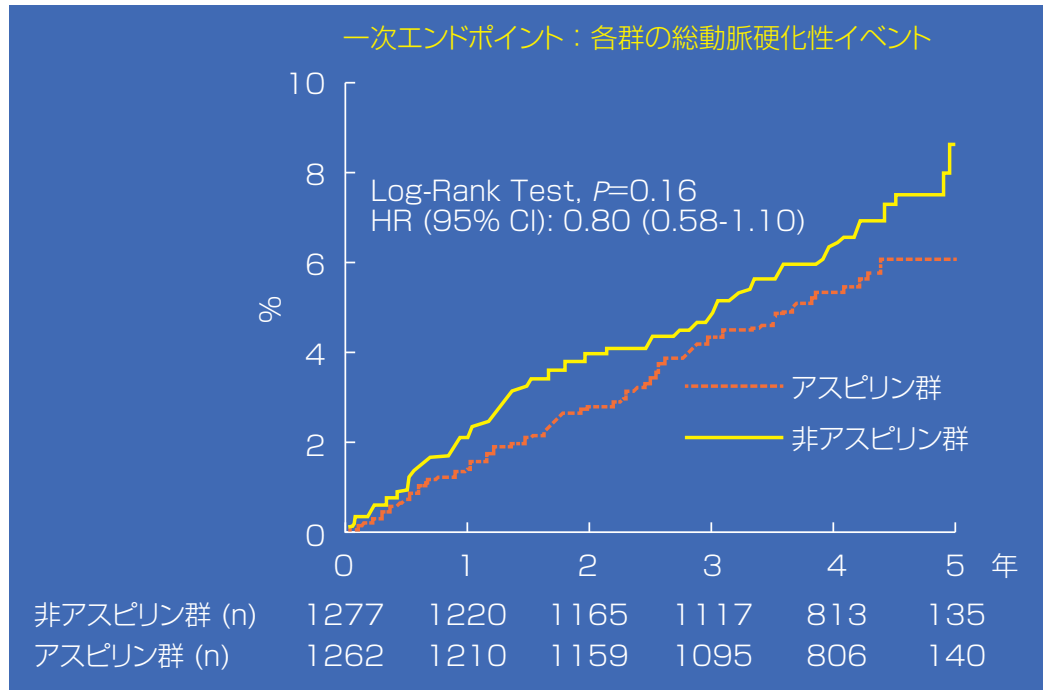

図 2. 総動脈硬化性イベントの累積発生率（Kaplan-Meier曲線）(文献 9 よ り引用)

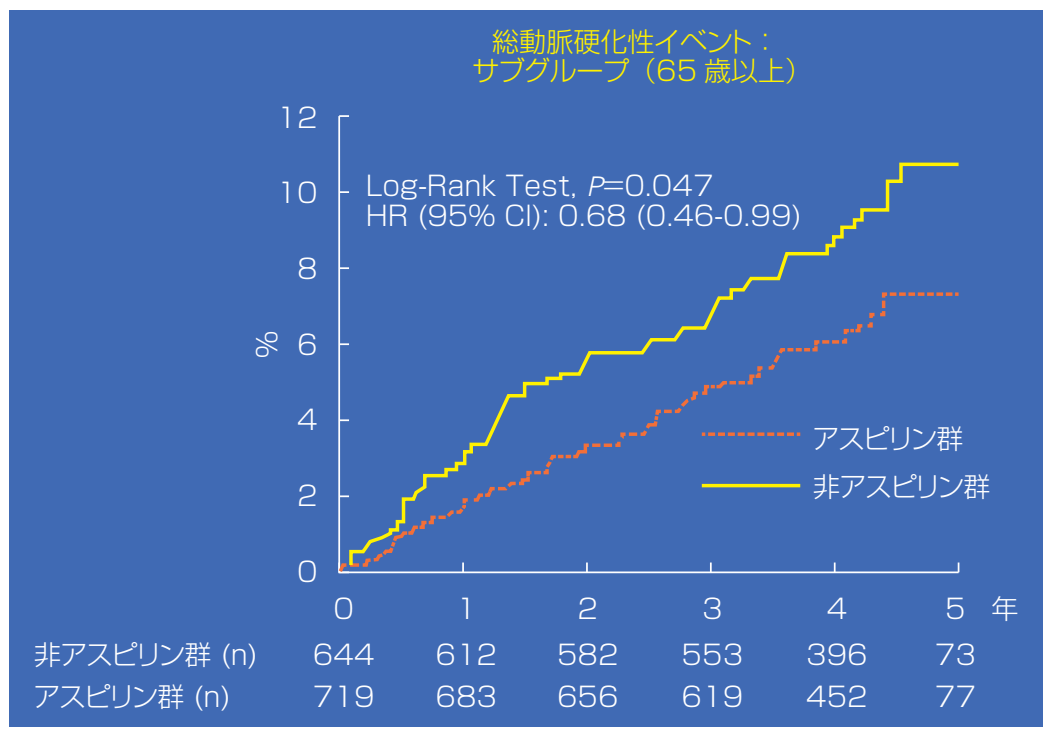

図 3. 65 歳以上の糖尿病患者の総動眽硬化性イベントの累積発生率 (Kaplan-Meier曲線)（文献 9 より）

みられなかった (図 2). 二次評価項目のうち, 致死性心筋梗塞と致死性脳卒中の合計を求めた ところ,アスピリン群 1 人(脳卒中), コントロー ル群 10 人 $(5$ 人が心筋梗塞, 5 人が脳卒中) に 起こり,ハザード比は 0.10(95\% 信頼区間 0.01〜
0.79, $\mathrm{p}=0.0037)$ で, アスピリン群で有意に少な いという結果であった。 サブグループ解析の結 果, 65 歳以上だけに限った場合に, ハザード比 が 0.68 (95\% 信頼区間 0.46〜0.99, p=0.047) と なり,アスピリン群に有意に少なかった（図 3). 
一方, 死亡は, アスピリン群 34 人, コントロー ル群 38 人に起こり, ハザード比は 0.90(95\% 信 頼区間 $0.57 \sim 1.14, \mathrm{p}=0.67$ ) で有意差はなかった. 追跡期間中に見られた有害事象に関しては，脳 出血および重症の消化管出血は, アスピリン群 10 人, コントロール群 7 人に起こったが有意差 はなかった。今回の試験で発生したイベント数 は, 久山町研究や舟形町研究といった疫学研究 を基に予想されたイベント数の 3 分の 1 で, 予 想を大きく下回った. アスピリンが全体的な心 血管イベントを有意差こそ出なかったが減少さ せたこと, 冠動脈死および脳血管死を減少させ たこと,また 65 歳以上の患者には効果があるこ とが示せたことは意義深い.

最近報告されたAntithrombotic Trialists' (ATT) Collaborationのメ夕解析では心血管疾患 一次予防に対するアスピリン療法は重篤な心血 管イベントの抑制には有用という結果であっ た ${ }^{10)}$. しかし, the Prevention of Progression of Arterial Disease and Diabetes (POPADAD) ${ }^{11)}$ と the Aspirin for Asymptomatic Atherosclerosis (AAA) trial ${ }^{12)}$ ではアスピリンの効果はなかった. 我々の見解としてはこれらの 2 つのトライアル はankle brachial index (ABI) がそれぞれ 0.99 以下と 0.95 以下であり, 登録患者は既に心血管 疾患を有している症例であり真に一次予防のト ライアルであったかどうかに疑問が残る ${ }^{13)}$.どの ような症例にベネフィットがリスクを上回るか を検討していく必要があるが, JPAD trialから日 本人において 65 歳以上の糖尿病患者は 1 つのア スピリン投与の基準となり得ると思われる.JPAD Trialは糖尿病の一次予防に関する代表的な研究 となり，2010 年のAmerican Diabetes Association, American Heart Association, American College of Cardiology Foundationからステート メントの中に引用されるに至った ${ }^{14 \sim 16)}$. すなわ ち共同声明をまとめると次のような結論になる, と考える。
男性 50 歳以上, 女性 60 歳以上で 1 つ以上major risk factor (喫煙, 高血圧, 脂質代謝異常症, 心疾患家族歴, 高血圧, 微量アルブミン尿) を 持つものは一次予防薬としてアスピリン服用が 推奨される. 当然ながら出血リスクのある患者 や低リスク患者には推奨されず, 中間リスクの ものに関しては考慮にとどまる.

\section{JPAD Trialの特徵}

Japanese Antiplatelets Myocardial Infarction Study (JAMIS), Japanese $\beta$-blockers and Calcium antagonists Myocardial Infarction (JBCMI) Study, Multicenter Study for Aggressive Lipid-lowering Strategy by HMG-CoA Reductase Inhibitors in Patients with Acute Myocardial Infarction (MUSASHI-AMI) は二次予防 試験であり, 関連病院や全国の知り合いの先生 の御協力で完成できた.しかし（JPAD）Trial は一次予防試験なので公立病院の糖尿病専門医 や開業医の先生に打願いするしかなく, 途方に 暮れていた. しかし, 本研究の発案者である奈 良県立医大の斎藤能彦教授, 当時大学にいて現 在は天草で開業されている中山雅文先生, 熊本 で開業されている糖尿病専門医の陣内冨男先生, 原口義邦先生, 坂本安弘先生, 国立循環器病セ ンターレジデント時代の同級生で静岡市立病院 の脇昌子先生, 大学時代の先輩で福岡の開業医 である花岡陽一先生, 玉名で開業されている菅 弘文先生, 大学の同級生でもある, 杏尾修一先 生, 20 年以上前から親しくさせていただいてい た旭川の横田裕光先生らの励ましでスタートし, 北海道から沖縄まで全国の開業医の先生方の御 協力で完成できた。 また, 論文作成の統計や構 成では京都大学医学教育推進センターの森本剛 先生に非常に御世話になった。 そして, 本研究 は 2008 年では糖尿病患者におけるアスピリンの 一次予防試験としては世界最大の試験となり, 
2008 年 11 月 9 日循環器では世界最大の学会であ るAmerican Heart Association (AHA) 2008 の会場となったNew Orleans Convention Center でLate-breaking Clinical Trialの第一日目に発表 出来た.JPADは同日JAMA-EXPRESSに同時掲 載された. AHA初日での発表さらに論文の同時 掲載は日本人で初めての事だった。会場には一 万人の聴衆が詰めかけ立錐の余地もなかった.

思い返せば, MUSASHI Studyの結果, 日本人 の心筋梗塞にもアメリカ人と同じょうにスタチ ンは有効であることを証明し, JAMIS, JBCMI studyは日本のガイドラインに引用された. 前述 のようにJAMISの頃は日本における臨床研究の 評価は低く, 実際日本循環器学会のポスター会 場で聴衆は 4 人という事もあった. JAMISは登 録から論文作成までほとんど一人で行った。平 日は登録を秘書の女性が手伝ってくれたが, 土, 日曜日は休み無く全国の循環器内科医からの対 応, 乱数表を用いての割付を行った. 連絡はファッ クスを用いて手書きで行った。 あまりにもアカ デミックでない仕事に嫌気もさしたが, 誰かが やらないといけないという義務感のみであった. ところがJBCMI studyの頃になると, 全国から注 目を浴び出し, MUSASHIでは臨床研究では日本 の第一人者の一人と評価されるに至った。しか し, 基礎研究の先生方が目標とし掲載されると 本当に喜ばれるNature, Cell, Scienceに負けな い雑誌にいつかはアクセプトされたいと常々思っ ていた. そのレベルの臨床雑誌はNew England Journal of Medicine, Lancet, JAMA (The Journal of the American Medical Association) しかな く未だ遠い存在であった。前述の基礎の雑誌は 日本からの採択は稀ではないが, 臨床の 3 大雑 誌には日本からはほとんど採択されていない. しかし, 大規模臨床研究を始めて 14 年目の 2008 年にそのチャンスが巡ってきたのであった。こ れは, AHAのLate-breaking Clinical Trialに採択 されたので巡ってきたチャンスと考え，一カ月
間は診療が終わって毎日午前 3 時くらいまで必 死で論文を書き, Reviewerへの回答もほぼ完壁 に行えた．夢の中でも論文を書いていたほどで あった. 午前 $2 \sim 3$ 時くらいに睡魔に襲われた時 はCCUにおいて徹夜で患者管理をしていた頃が 走馬燈のように想い浮かび頑張ることができた. やはりこの点でも長い臨床経験が生かされたと 思う。

\section{4. 今後の展望}

我々は日本における抗血小板療法のエビデン スとしてのJapanese Antiplatelets Myocardial Infarction Study (JAMIS), 心筋梗塞後のイベン 卜抑制に対するCa拮抗薬と $\beta$ 遮断薬の比較試験で あるJapanese $\beta$-blockers and Calcium antagonists Myocardial Infarction (JBCMI) Study, 急 性心筋梗塞に対するスタチン療法の効果を検討 したMulticenter Study for Aggressive Lipidlowering Strategy by HMG-CoA Reductase Inhibitors in Patients with Acute Myocardial Infarction(MUSASHI-AMI)を行ってきた。また, 一次子防試験であるTrial Japanese Primary Prevention of Atherosclerosis with Aspirin for Diabetes（JPAD）Trialを行い本稿で解説した。 日 本人と欧米人では環境や病態が異なるので治療 についても日本人独自のエビデンスが必要になっ てくる.今後も様々な治療法に関して多施設共 同大規模無作為試験による日本でのエビデンス 出現が望まれる。

著者のCOI (conflicts of interest) 開示: 小川久雄 ; 講演料 (エーザイ, サノフィ・アベンティス, 第一三共, バイエル薬 品), 研究費 - 助成金 (契煙科学研究財団, 第一三共), 寄付 金 (エーザイ, サノフィ・アベンティス, 第一三共, バイエ ル薬品)

\section{文献}

1) ISIS-2 (Second International Study of Infarct Sur- 
vival) Collaborative Group : Randomised trial of intravenous streptokinase, oral aspirin, both or neither among 17,187 cases of suspected acute myocardial infarction : ISIS-2. Lancet $2:$ 349-360, 1988.

2) $\beta$-blocker Heart Attack Trial Research Group : A randomized trial of propranolol in patients with acute myocardial infarction. I. Mortality results. JAMA 247 : 17071714,1982

3) Pfeffer MA, et al: Effect of captopril on mortality and morbidity in patients with left ventricular dysfunction after myocardial infarction Results of the survival and ventricular enlargement trial. The Save investigators. N Engl J Med 327 : 669-677, 1992.

4) Scandinavian Simvastatin Survival Study Group : Randomized trial of cholesterol lowering in 4444 patients with coronary heart disease : the Scandinavian Simvastatin Survival Study (4S). Lancet $344:$ 1383-1389, 1994.

5) Schwartz GG, et al. for the Myocardial Ischemia Reduction with Aggressive Cholesterol Lowering (MIRACL) Study Investigators : Effects of Atorvastatin on early recurrent ischemic events in acute coronary syndromes. JAMA 285 : 1711-1718, 2001.

6) Yasue H, et al., on behalf of the Japanese Antiplatelets Myocardial Infarction Study (JAMIS) investigators: Effects of aspirin and trapidil on cardiovascular events after acute myocardial infarction. Am J Cardiol 83: 13081313,1999

7) The Japanese $\beta$-blockers and Calcium antagonists Myocardial Infarction (JBCMI) Investigators : Comparison of the effects of beta-blockers and calcium antagonists on cardiovascular events after acute myocardial infarction in Japanese subjects. Am J Cardiol 93 : 969-973, 2004.

8) Sakamoto $T$, et al. on behalf of the Multicenter Study for Aggressive Lipid-Lowering Strategy by HMG-CoA Reductase Inhibitors in Patients With Acute Myocardial Infarction (MUSASHI-AMI) : Effects of early statin treatment on symptomatic heart failure and ischemic events after acute myocardial infarction in Japanese. Am J Cardiol 97 : 1165-1171, 2006.

9) Ogawa $\mathrm{H}$, et al, for the Japanese Primary Prevention of Atherosclerosis With Aspirin for Diabetes (JPAD) Trial
Investigators : Low-dose aspirin for primary prevention of atherosclerotic events in patients with type 2 diabetes. A randomized controlled trial. JAMA 300:2134-2141, 2008.

10) Antithrombotic Trialists'(ATT) Collaboration, Baigent $\mathrm{C}$, et al: Aspirin in the primary and secondary prevention of vascular disease: collaborative meta-analysis of individual participant data from randomised trials. Lancet 373 : 1849-1860, 2009.

11) Belch J, et al : The prevention of progression of arterial disease and diabetes(POPADAD) trial : factorial randomised placebo controlled trial of aspirin and antioxidants in patients with diabetes and asymptomatic peripheral arterial disease. BMJ 337 : a1840, 2008.

12) Fowkes FG, et al: Aspirin for asymptomatic atherosclerosis trialists. Aspirin for prevention of cardiovascular events in a general population screened for a low ankle brachial index : a randomized controlled trial. JAMA 303 : 841-848, 2010.

13) Soejima $H$, et al : Aspirin for the primary prevention of cardiovascular events in patients with peripheral artery disease or diabetes mellitus. Thrombosis and Haemostasis 104 : 1085-1088, 2010.

14) A position statement of the American Diabetes Association, a scientific statement of the American Heart Association, and the expert consensus document of the American College of Cardiology Foundation. Aspirin for primary prevention of cardiovascular events in people with diabetes. Diabetes Care 33 : 1395-1402, 2010.

15) A position statement of the American Diabetes Association, a scientific statement of the American Heart Association, and the expert consensus document of the American College of Cardiology Foundation. Aspirin for primary prevention of cardiovascular events in people with diabetes. JACC 55 : 2878-2886, 2010.

16) A position statement of the American Diabetes Association, a scientific statement of the American Heart Association, and the expert consensus document of the American College of Cardiology Foundation. Aspirin for primary prevention of cardiovascular events in people with diabetes. Circulation 121 : 2694-2701, 2010. 